\title{
Chronic Propionibacterium acnes prosthesis joint infection manifesting as a large abscess with gas, without prosthesis loosening
}

\author{
Marjolie Lorillou, ${ }^{1,2}$ Benoit Martha, ${ }^{3}$ Christian Chidiac, ${ }^{1,2,4}$ Tristan Ferry, $^{1,2,4}$ on behalf \\ of the Lyon Bone and Joint Infection Study Group
}

${ }^{1}$ Service de Maladies Infectieuses et Tropicales, Hôpital de la Croix-Rousse, Hospices Civils de Lyon, Lyon, France

${ }^{2}$ Université Claude Bernard Lyon 1, Lyon, France ${ }^{3}$ Service de Maladies Infectieuses et Tropicales, Centre Hospitalier William Morey, Chalon-sur-Saône, France

${ }^{4}$ Centre International de Recherche en Infectiologie (CIRI), Inserm U1111, CNRS UMR5308, ENS de Lyon, UCBL1, Lyon, France

\section{Correspondence to}

Dr Tristan Ferry,

tristan.ferry@univ-lyon1.fr

\section{CrossMark}

To cite: Lorillou $\mathrm{M}$, Martha B, Chidiac C, et al. BMJ Case Rep Published online: [please include Day Month Year] doi:10.1136/ bcr-2013-201090

\section{DESCRIPTION}

A 78-year-old woman with diabetes, hypertension and severe omarthrosis, had a left total shoulder arthroplasty in May 2010. In September 2010, the patient developed axillar abscess, without fever or pain, which was incised. Propionibacterium acnes grew in cultures and the patient received amoxicillin-clavulanate for 10 days. In 2011, it reoccurred, with abscess formation that gradually increased in size during several weeks and reached $5 \times 8 \mathrm{~cm}$ in diameter (figure $1 \mathrm{~A}$ ). C reactive protein was elevated $(94 \mathrm{mg} / \mathrm{L})$, but the patient did not have fever. X-ray examination did not show prosthesis loosening, but a distal cortical thickening of the humerus without a typical periosteum reaction was depicted (figure 1B). A CT scan revealed gas production in a large abscess (figure 1C). Implant removal was performed and $P$ acnes grew rapidly from all perioperative samples. The outcome was favourable under antimicrobial therapy which included amoxicillin and clindamycin.

$P$ acnes is a commensal Gram-positive anaerobe (with fermentation process in vitro) ${ }^{1}$ of the skin and is a frequent pathogen involved in postoperative shoulder prosthesis infection. ${ }^{2}$ P acnes is a slow-growing bacterium and (1) most patients have prosthesis loosening years after implantation, without abscess nor gas formation (whereas abscess and gas production has been reported in patients with delayed subdural empyema) ${ }^{3}$ and (2) most $P$ acnes responsible for prosthesis infection grow slowly (10-14 days) in enrichment culture media. ${ }^{2}$ In chronic prosthetic joint infection, the implant has to be removed and at least 6 weeks of antimicrobial therapy is generally required. Large abscess formation with gas production is atypical in patients with chronic $P$ acnes postoperative prosthetic joint infection. Practitioners aware of this clinical presentation can pertinently include it in their differential diagnosis.

\section{Learning points}

- Propionibacterium acnes is one of the most frequent bacteria involved in chronic prosthesis shoulder infections.

- Typically, $P$ acnes postoperative prosthesis infections are usually chronic, without local signs of infection and without fever, and are associated with prosthesis loosening.

- However, $P$ acnes postoperative prosthesis infections could be associated with large abscess formation with gas production.
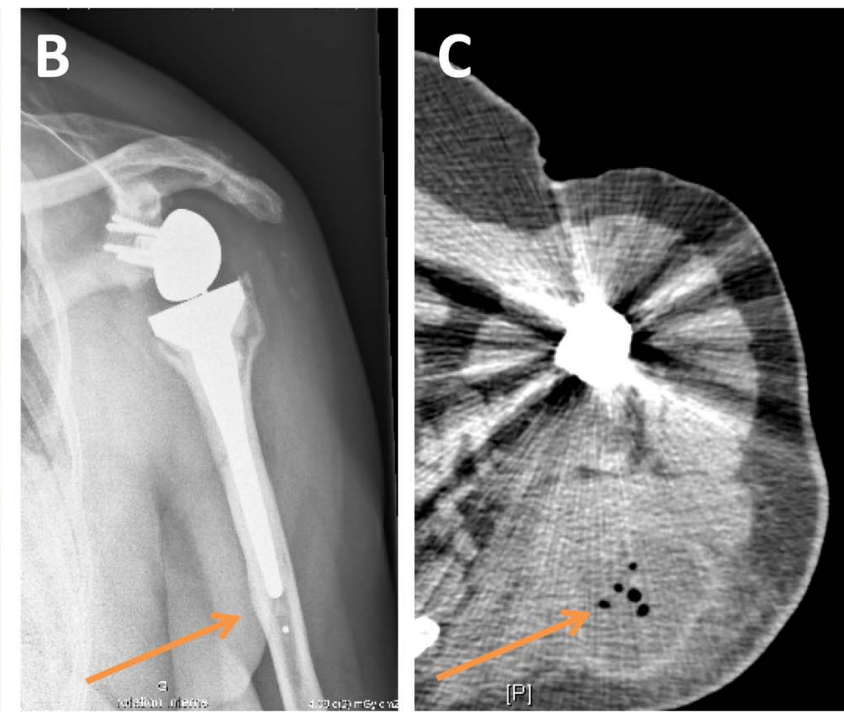

Figure 1 Clinical aspect of the large abscess (A) with distal cortical thickening on X-ray (arrow, B) and gas on CT scan (arrow, C). 
Collaborators Lyon Bone and Joint Infection Study Group: Physicians-Tristan Ferry, Thomas Perpoint, André Boibieux, François Biron, Florence Ader, Judith Karsenty, Florent Valour, Fatiha Daoud, Johanna Lippman, Evelyne Braun, Marie-Paule Vallat, Patrick Miailhes, Christian Chidiac, Dominique Peyramond, Surgeons-Sébastien Lustig, Philippe Neyret, Olivier Guyen, Jean-Baptiste Bérard, Romain Desmarchelier, Michel-Henry Fessy, Cédric Barrey, Francesco Signorelli, Pierre Breton, Ali Mojallal, Fabien Boucher; Microbiologists-Frederic Laurent, François Vandenesch, Jean-Philippe Rasigade; Nuclear Medicine—-Isabelle Morelec, Marc Janier, Francesco Giammarile; PK/PD specialists-Michel Tod, Marie-Claude Gagnieu, Sylvain Goutelle; Clinical Research Assistant—Eugénie Mabrut.

Contributors All the authors participated in the patient care, the literature review and the writing of the article.

Competing interests None.

Patient consent Obtained.
Provenance and peer review Not commissioned; externally peer reviewed.

\section{REFERENCES}

1 Singh JA, Sperling JW, Schleck C, et al. Periprosthetic infections after total shoulder arthroplasty: a 33-year perspective. I Shoulder Elbow Surg 2012;21:1534-41.

2 Shu M, Wang Y, Yu J, et al. Fermentation of propionibacterium acnes, a commensal bacterium in the human skin microbiome, as skin probiotics against methicillin-resistant Staphylococcus aureus. PLoS ONE 2013;8:e55380.

3 Ghalayini SR, Likhith AM, Golash A. Propionibacterium acnes causing delayed subdural empyema - a case report and review of literature. I Clin Neurosci 2004;11:677-9.

Copyright 2013 BMJ Publishing Group. All rights reserved. For permission to reuse any of this content visit http://group.bmi.com/group/rights-licensing/permissions.

BMJ Case Report Fellows may re-use this article for personal use and teaching without any further permission.

Become a Fellow of BMJ Case Reports today and you can:

- Submit as many cases as you like

- Enjoy fast sympathetic peer review and rapid publication of accepted articles

- Access all the published articles

- Re-use any of the published material for personal use and teaching without further permission

For information on Institutional Fellowships contact consortiasales@bmjgroup.com

Visit casereports.bmj.com for more articles like this and to become a Fellow 